\title{
Microfinance Position and Indebtedness: Empirical Evidence from Microfinance Institutions in Nepal
}

\author{
Nischal Risal \\ Lecturer, Nepal Commerce Campus
}

\begin{abstract}
The paper has been built up with the aim of analyzing the microfinance institutions status and indebtedness in Nepal. Initially, the paper starts with the thematic review based on etymological, ontological, epistemological dimensions then the status of microfinance institutions and indebtedness in Nepal have been presented in the second part. The descriptive analytical research design has been adopted to analyze and interpret the population data. The fifty three microfinance institutions' data have been reviewed, tabulated and analyzed using MSExcel. The microfinance institutions have been found efficient in saving and credit services. The microfinance credit service has not been utilized as per the need of the people and capacity of the institutions. The loan recovery, interest recovery, clients awareness/activeness have been found effective. Overall, microfinance institutions status has been found sound. Only few institutions are below the satisfaction level. The microfinance services in terms of micro loan are not uniform among microfinance institutions. The indebtedness challenge have found at bottom level in the microfinance industry. It is recommended to all the microfinance institutions to come up with policies, strategies and regulatory framework to benchmark the level of tolerance to indebtedness, so that the microfinance institutions may sustain by achieving the objectives of poverty alleviation through microfinance services.
\end{abstract}

Keywords: Microfinance, Indebtedness, Micro Credit, Micro Saving, Clients

\section{Prologue}

All over the world, microfinance institutions are providing their services to low income under-privilege people in the society to eliminate the poverty. The microfinance services and product rendered to the society are differing from one society to another society, one institution to another institution. The effectiveness becomes high success in microfinance sectors, even though the problem of indebtedness arises simultaneously. The consumer is over-indebted when he/she is unable to pay all his/her financial obligations timely as agreed in a credit agreement. This could either be because his/ her financial commitments have changed or because the individual has borrowed and spent more money than he/she earns. In such instances, the debt becomes a major burden for the borrower, which contributes to the consumer's social and financial exclusion, and poverty.

The poverty, adverse shocks, low returns and financial literacy may be the major factors that are relate to indebtedness in microfinance. The factors were broken down 
to the specific sacrifices that borrowers made, to how frequently they had repeated them, and to how acceptable sacrifices were to borrowers. The poorer micro-borrowers were more likely to be over-indebted, the risk of over-indebtedness further increased with the occurrence of adverse economic shocks to a borrower's income or expenses, the likelihood of over-indebtedness was higher for borrowers with low returns on their investment and if borrowers had used loans at least in part for non-productive purposes, and it was higher for borrowers with low, debt-specific financial literacy. General financial literacy had negative effects on over-indebtedness (Schicks, 2012).

The literature on consumer finance in developed countries had extensively analyzed why borrowers had entered into burdensome levels of debt and what for what borrowers the risk of personal over-indebtedness become particularly high (Bridges \& Disney, 2004; Lea, Webley, \& Walker, 1995; Lusardi \& Tufano, 2009; Webley \& Nyhus, 2001). There is a limited amount of research on delinquency and default in microfinance (Godquin, 2004; Schreiner, 2004; Vogelgesang, 2003), but hardly any research on over-indebtedness. With increasing concerns about negative effects of microfinance on customers, at a time where trust in the positive impact of microfinance is weakening (Duvendack, et. al., 2011; Karlan \& Goldberg, 2011), overindebtedness is one of the most pressing challenges facing the microfinance industry. It endangers at the same time the sustainability of microfinance institutions (MFIs) and their social impact (Schicks, 2012).

Viada and Gaul (2012) revealed that the microcredit markets become fragile. The poor had limited absorptive capacity for debt and could easily over-extend themselves by taking on debt obligations in excess of what they could reasonably hope to service. While ambitious MFI outreach goals were to be applauded in principle, the reality was that overly zealous loan origination activities could override governance and control systems, leading to less rigorous credit standards and destructive, unintended consequences.

People in precarious economic circumstances are under enormous pressure to secure resources for their families, making them very susceptible to offers of easy credit. When they are unable to keep the repayment schedule (again, often due to family circumstances), they may weakly negotiate with their lender, but eventually find a way to pay, even if it means going deeper into debt. Ultimately, the lender regains its capital, usually with interest and penalties, but the borrower's economic prospects are worsened (Ericksen and Ericksen, 2014).

Though the risk of indebtedness is growing concern worldwide, it might be arise due to unhealthy competition, triggering of the microfinance activities by banks, unchecked growth of microfinance institutions, traditional microfinance system of providing the services and risk of mission drift. On the prevailing ground of literature, the study aims towards exploring the thematic remarks on the given issue and triangulate empirically with an evidence of microfinance institutions in Nepal.

\section{Etymological Dimension of Microfinance and Indebtedness}

The word micro is derived from a Greek word mikros which means small. The word Finance has its origin from the word fin from old French, which was later used as finer. Later, merger of words led to creation of word finance in late Middle English. The word finance was given by the Aristotle near about two thousand years ago when there 


\section{Pravaha Journal-2018}

was no concept of financing and related issues. In Aristotle's politics book I, it is clearly mentioned by the author that the finance is a related term that all the countries and government face the situations in which sometimes they need money to buy households and other things important for the life. The people who are not involved in trade and business also need to learn about the finance. Aristotle's explanation was restricted to those involved with the economic and financial operations of the government and countries but a type of finance concerning marketable nautical and other kinds of jobs loaning thrived in the prehistoric world. The suggestion of the word started to modify over the time as it traveled from different countries. The word finance first discovered in Latin then into old French word the finaunce.

In 1700's, the word started to have a unclearly pessimistic logic as it was used to the behaviors of those involved working in Finance of Courts, the word rentiers was used for those people. The sovereignty of that epoch would not doubt ask for to vary as they would not have been able fight with their enemies without having money that comes from the rentiers. In England, an opposed outline was seen with the association of the finance as it rapidly came to be connected with an important commotion. This occurred because the people who were affianced in the doings of Court Finance prearranged themselves politically in order to defend their benefits, wellbeing and comforts in opposition to random royal elimination. At that time, it was felt that the reinters would occupy the royal monarchy to approve new loan schemes and trades. The considerations became true when the royal monarchy approved the loaning trades and business in the country to save the royal succession.

The sagacity of the connotation of the word finance long-drawn-out and became even more optimistic as the previous groups of Court investors lengthened the rapidly increasing region of business and other profitable financing projects. As early as 1800 in the countries where English was the first language the term finance become more popular and similar to the word that is used now days. The beginning of different terms related to finance such as debt, credit, equity, profits and losses has a great history. Microcredit, or microfinance, means banking the unbankables, bringing credit, savings and other essential financial services within the reach of millions of people who are too poor to be served by regular banks, in most cases because they are unable to offer sufficient collateral. The word debt is based on the Latin word debitum (something owed/thing owed) whose past participle debere means owe/to owe. In Old French this Latin word was changed to dete and in Middle English to dette with its modern day French and English spelling being debt.

Roman Catholics and Anglicans, had used the phrase forgive us our trespasses. Trespass is from the Old French trespass, meaning a passing across or transgression of the law (The word transgression exhibits the same semantic development. The roots literally mean a passing across, but it has come to mean a violation of law). In 1290 in the South English Legendary, the sense of trespass meaning to enter private property without permission appears somewhat later and was often fashioned trespass to land in legal documents. The author of Matthew, writing in Greek, uses the word opheilemata, which had a literal meaning of financial debt, but which also had a metaphorical sense of spiritual obligation. This sense of debt meaning spiritual obligation was also present in Aramaic writings of the period and Jesus, who spoke and taught in Aramaic, used this metaphor in various parables.

122 | A Journal of Management 


\section{Ontology Dimension of Microfinance and Indebtedness}

Microfinance is the process of providing financial assistance as well as other services such as insurance and savings to underprivileged people while microcredit is one aspect of microfinance and is the process of extending credit to the poor. Microfinance was developed for people who find it hard to get financial assistance from mainstream institutions while microcredit was developed to provide credit and loans to the same people. However, a number of crises in the industry have recently threatened both financial sustainability and the industry's social reputation. There are concern about microfinance institutions drifting away their original social mission (Labie and Mersland, 2010; Mersland and Storm, 2010; Armendariz and Szafarz, 2011). While the social mission of microfinance industry gives specific importance to protecting the interest of customer, the 2008/2009 global banking crises has pointed out that an unsustainable financial services offer based on irresponsible lending implies risk for the industry as a whole. In this context, over-indebtedness is currently one of the most serious risks of microfinance, endangering both social impact and industry stability. It has the potential to push customers further into poverty, accompanied by the material, psychological and sociological consequences of debt. Increasingly rigorous impact studies are questioning the original impact and poverty alleviation of microfinance (Banerjee, et.al, 2014; Karlan and Zinman, 2010). Microfinance customers have good reasons to take loans but little reason to borrow to the extent of over indebtedness. Neither should lenders and even less so MFIs with a social mission have an interest in over indebting their customers. Overindebtedness is thus an undesired consequence for both parties and in perfect markets should not exist.

One set of factors that can push borrowers into over indebtedness is outside the control of the lending parties. In spite of sound lending decisions, external shocks to the income or expenses of a micro borrower can turn a debt load unsustainable. Bouquet, et. al. (2007) confirmed that credit problems were most frequently due to drops in expected income or rising expenses. Besides personal shocks such as illness or job loss, macroeconomic developments such as the financial crisis could drive borrowers into such difficulties.

Whatever the institutional environment, over-indebtedness is ultimately created by the parties that make the credit decision makers; lenders and borrowers. The three major levers of lending behavior that enhance over indebtedness risks are an excessive marketing and growth focus, unsuitable product characteristics, and the favorable lending procedures. Finally, micro lenders contribute to overindebtedness with their lending procedures. The most important lender contribution probably stems from an evaluation of repayment capacity and the automatic increases in loan sizes over time. A customer protection perspective should therefore resist the temptation of seeking fault only with lenders and with adverse circumstances. It should equally pay attention to the role that borrowers themselves play in destructive credit. It should recognize that to a certain extent, protecting borrowers from over-indebtedness may mean protecting them from themselves.

Among external influences, adverse shocks to the income or expenses can turn debt unmanageable. In microfinance markets in developing countries, institutional protection from overindebtedness may be weak. MFIs can push borrowers beyond their limits due to an exaggerated focus on portfolio growth and by means of aggressive 
marketing techniques. They sometimes offer products that are inappropriate to the borrower's situation, enforce unrealistic installment schedules, resist the need to reschedule loan agreements, artificially limit maturities and so on. Micro lenders also contribute to over-indebtedness due to their operating procedures, being lax about evaluating repayment capacity, offering in transparent terms and conditions and using coercive collection practices. Finally, micro borrowers play an important role in their own over-indebtedness. Due to cognitive limitations, difficulties to resist temptation, and sociological pressures, they sometimes make irresponsible borrowing decisions. The tendency towards over borrowing also depends on borrowers' socio demographic and economic characteristics, many of those that are related to over indebtedness being particularly prominent among the microfinance target group.

If a credit relationship leads to over indebtedness that is usually the result of interacting factors. If a borrower made perfectly informed, rational decisions, not giving in to temptation or social pressures, an MFI would face little risk to over-indebt this customer. At the same time, if an MFI put its social mission and customer interest above all other goals, designed products that perfectly matched their customers' needs, carefully evaluated repayment capacity and took the psychological limitations and biases of their customers into account in their communication and lending decisions, even imprudent borrowers would hardly be at risk. In reality, both parties are bound to make mistakes given the complexity of the situation and their information asymmetries. It is therefore important to design measures to prevent over-indebtedness that tackle as many of the over-indebtedness reasons as possible. For the remaining micro borrowers that can still not be protected from over-indebtedness, additional curative and rehabilitative customer protection measures are required.

\section{Epistemology Dimension of Microfinance and Indebtedness}

Savings and credit groups that have operated for centuries include the susus of Ghana, chit funds in India, tandas in Mexico, arisan in Indonesia, cheetu in Sri Lanka, tontines in West Africa, and pasanaku in Bolivia, as well as numerous savings clubs and burial societies found all over the world were acting the functions of microfinance. Formal credit and savings institutions for the poor have also been around for decades, providing customers who were traditionally neglected by commercial banks a way to obtain financial services through cooperatives and development finance institutions. One of the earlier and longer-lived micro credit organizations providing small loans to rural poor with no collateral was the Irish Loan Fund system, initiated in the early 1700 s by the author and nationalist Jonathan Swift. Swift's idea began slowly but by the 1840s had become a widespread institution of about 300 funds all over Ireland. Their principal purpose was making small loans with interest for short periods. At their peak they were making loans to $20 \%$ of all Irish households annually. In 1800 s, various types of larger and more formal savings and credit institutions began to emerge in Europe, organized primarily among the rural and urban poor. These institutions were known as People's Banks, Credit Unions, and Savings and Credit Co-operatives.

In 1972 the Self Employed Women's Association (SEWA) was registered as a trade union in Gujarat (India), with the main objective of strengthening its members bargaining power to improve income, employment and access to social security. In 1973, to address their lack of access to financial services, the members of SEWA 
decided to found a bank of their own. Four thousand women contributed share capital to establish the Mahila SEWA Co-operative Bank. Since then it has been providing banking services to poor, illiterate, self-employed women and has become a viable financial venture with today around 30,000 active clients. In Bangladesh, Professor Muhammad Yunus addressed the banking problem faced by the poor through a programme of action-research. With his graduate students in Chittagong University in 1976, designed an experimental credit programme to serve them. It was spread rapidly to hundreds of villages. Through a special relationship with rural banks, he had disbursed and recovered thousands of loans, but the bankers refused to take over the project at the end of the pilot phase. They feared it was too expensive and risky in spite of his success. Eventually, through the support of donors, Grameen Bank was founded in 1983 and now serves more than four million borrowers. The initial success of Grameen Bank had stimulated the establishment of several other giant microfinance institutions like BRAC, ASA, Proshika, etc.

Through the 1980s, the policy of targeted, subsidized rural credit came under a slow but increasing attack as evidence mounted of the disappointing performance of directed credit programs, especially poor loan recovery, high administrative costs, agricultural development bank insolvency, and accrual of a disproportionate share of the benefits of subsidized credit to larger farmers. The basic tenets underlying the traditional directed credit approach were debunked and supplanted by a new school of thought called the financial systems approach, which viewed credit not as a productive input necessary for agricultural development but as just one type of financial service that should be freely priced to guarantee its permanent supply and eliminate rationing. The financial systems school held that the emphasis on interest rate ceilings and credit subsidies retarded the development of financial intermediaries, discouraged intermediation between savers and investors, and benefited larger scale producers more than small scale, low-income producers.

Meanwhile, microcredit programs throughout the world improved upon the original methodologies and defied conventional wisdom about financing the poor. First, they showed that poor people, especially women, had excellent repayment rates among the better programs, rates that were better than the formal financial sectors of most developing countries. Second, the poor were willing and able to pay interest rates that allowed microfinance institutions (MFIs) to cover their costs. 1990s These two features - high repayment and cost-recovery interest rates permitted some MFIs to achieve long-term sustainability and reach large numbers of clients.

Another flagship of the microfinance movement is the village banking unit system of the Bank Rakyat Indonesia (BRI), the largest microfinance institution in developing countries. This state-owned bank serves about 22 million micro savers with autonomously managed micro banks. The micro banks of BRI are the product of a successful transformation by the state of a state-owned agricultural bank during the mid 1980s.

The 1990s saw growing enthusiasm for promoting microfinance as a strategy for poverty alleviation. The microfinance sector blossomed in many countries, leading to multiple financial services firms serving the needs of micro entrepreneurs and poor households. These gains, however, tended to concentrate in urban and densely populated rural areas. It was not until the mid-1990s that the term microcredit began 
to be replaced by a new term that included not only credit, but also savings and other financial services. "Microfinance" emerged as the term of choice to refer to a range of financial services to the poor, that included not only credit, but also savings and other services such as insurance and money transfers. ACCION helped found BancoSol in 1992, the first commercial bank in the world dedicated solely to microfinance. Today, BancoSol offers its more than 70,000 clients an impressive range of financial services including savings accounts, credit cards and housing loans.

Today, practitioners and donors are increasingly focusing on expanded financial services to the poor in frontier markets and on the integration of microfinance in financial systems development. The recent introduction by some donors of the financial systems approach in microfinance - which emphasizes favorable policy environment and institution-building - has improved the overall effectiveness of microfinance interventions. But numerous challenges remain, especially in rural and agricultural finance and other frontier markets. Today, the microfinance industry and the greater development community share the view that permanent poverty reduction requires addressing the multiple dimensions of poverty. For the international community, this means reaching specific Millennium Development Goals (MDGs) in education, women's empowerment, and health, among others. For microfinance, this means viewing microfinance as an essential element in any country's financial system. The examples of innovations in financial services for the poor were an International Remittance Network (IRnet), Unibanka (Latvia), ICICI Bank (India), Microenterprise Access to Banking Services (MABS), BASIX, The National Microfinance Bank in Tanzania (NMB), Banco Postal in Brazil, and Equity Building Society (EBS) in Kenya etc.

While the concept had been used globally for centuries, it was Bangladesh's Muhammad Yunus who was credited with being the pioneer of the modern version of microfinance. The year 2005 was proclaimed as the International year of Microcredit by The Economic and Social Council of the United Nations in a call for the financial and building sector to fuel the strong entrepreneurial spirit of the poor people around the world. The International year of Microcredit consisted of five goals. they were to assess and promote the contribution of microfinance to the MFIs. To make microfinance more visible for public awareness and understanding as a very important part of the development situation. The promotion should be inclusive the financial sector. To make a supporting system for sustainable access to financial services. To support strategic partnerships by encouraging new partnerships and innovation to build and expand the outreach and success of microfinance for all.

Professor Mohammad Yunus was awarded by the Nobel Prize 2006 for the efforts to create economic and social development from baseline. The loans to poor people without any financial security had appeared to be an impossible idea. From modest beginnings three decades ago, Yunus had, first and foremost through Grameen Bank, developed micro-credit into an ever more important instrument in the struggle against poverty.

\section{Microfinance Position and Indebtedness in Nepal}

The history of microfinance in Nepal is relatively new. The Nepali government's attempt to promote microfinance services dates back to 1975. It was recognized as an official poverty alleviation tool only in the country's Sixth Plan (1980/81-1984/85). The 
sector had, however, gained momentum after the restoration of democracy in 1991. Despite its tremendous potential to alleviate human poverty, only 33 percentages of households below the poverty line have access to microfinance services. The microfinance sector was served by cooperatives (1950-1960s) and normal banks (19701980s) until 1980, when a number of pilot projects and initiatives were implemented to introduce the financial and banking services to help poor and women. However, few groups of poor people were benefited, but at the end these service were found ineffective. There is an even greater need to expand microfinance services in the high hills and mountainous regions of the country.

During the 1990s and early 2000s, the government moved further to strengthen the microfinance institutions to provide financial service to poor and women, with the formation of five Regional Development Banks (RDBs) in each Development region based of Grameen model with the sole objective to provide micro-credit services to the poor and women. Eventually these Regional Development Banks transformed to Microfinance Development Banks (MFDBs) after privatization and licensed as class 'D' financial Institutions. Nepal Rastra Bank, the central bank of the country regulates the Microfinance Development Banks (MFDBs) and Financial Intermediary NGOs (FINGOs) while the Small Farmer Cooperatives Ltd. (SFCL) and Savings and Credit Cooperatives (SACCOs) are governed by Cooperative Laws. All types of Microfinance services in the country are provided by Microfinance Institutions (MFIs) working as regulated MFDBs, FINGOs, SFCL, and SACCOs.

Nepal has an experience of about four decades in microfinance. Although many programmes have been implemented for poverty lessening initiatives Nepal, only microfinance programmes are seen as pro-poor and rural based. A variety of microfinance development programmes including deprived sector credit programme as well as other donor supported micro credit programs were launched during the period. Microfinance has been particularly recognized as an effective development intervention for basic three reasons; the services provided through microfinance can be targeted specifically to the poor and poorest of the poor, these services can make a significant contribution to the socio-economic status of targeted community and the institutions that deliver these services can develop within few years, into sustainable organizations with steady growing outreach. Difficult topography, remoteness, heterogeneous groups and culture, etc. have hindered for the successful delivery of micro-finance in Nepal. Some microfinance outreach studies have revealed that microfinance activities are still untouched to the poor and rural households in remote Terai, Hill and Mountain Regions (NRB, 2013).

Nepal is highly heterogeneous in terms of population density, per capita income, poverty incidence, economic structure and social development. Great variations exist across development region and ecological belt in term of physical and financial infrastructure facilities; macroeconomic stability and policy environment for growth in general and microfinance in particular. These factors together with legal framework have a significant bearing on existing state of outreach and operational and financial self-sufficiency of actors in Nepalese microfinance industry (Dhakal, 2007).

The level of competition in Nepalese microfinance industry is gradually increasing leading to penetration to a significant proportion of potential market. In some villages, clients are able to choose between as many as seven microfinance service providers to 


\section{Pravaha Journal-2018}

access microfinance services which have driven many clients into over-indebtedness due to absence of institutional mechanisms for sharing credit information among MFIs and issue of encroachment or unfair competition is gradually emerging as an issue. Owing to limited number of suppliers, similar problems are yet to emerge in hills and mountains and there are areas where poor are desperately looking for microfinance services.

\section{Methods and Analysis of Data}

The information on the microfinance has shown the microfinance institutions micro credit services in Nepal. The data have been extracted from reports published by Nepal Rastra Bank. The study has covered all fifty three microfinance institutions operating in Nepal. The study is based on the data collected through published report of microfinance institutions up to $2017 \mathrm{AD}$. The descriptive statistical measures have been used to analyze and interpret the data. The triangulation between primary survey and secondary data has not been done in the study. As stated in literature, the current data has identified the microfinance indebtedness problem in Nepal. The study revealed that twenty one microfinance institutions have access to all 75 districts, whereas remaining microfinance institutions service ranges from nil to 32 districts. Nirdhan Utthan, Deprosc, Chimek, Swablamban, Nerude, and Forward microfinance institutions have more than one hundred thousand members. NRB has not published the data of Sparsh microfinance which become inherent limitation of population data.

The microfinance institutions are providing services to approximately twenty three and half peoples all over the Nepal. The negligible 1.55 percentage become passive members. Nepal Grameen Bikas Bank has 19801 passive members, which is the highest among all. Approximately 62.22 percentage of total microfinance do not have any passive members. The total number of debt holders receiving services from the microfinance institutions is approximately sixteen hundred thousand for the fiscal year 2073/74 B.S. The highest micro credit service providers in numbers are Nepal Grameen Bikas Bank, Forward, Nerude, Nirdhan Utthan Bank, Chimmek, Deprosc and Swablamban microfinance institutions. The total loan distribution by the microfinance institutions figure to around 5.14 billion in rupees. Out of which, 79 percentage in approx is recovered whereas remaining approximately 21 percentage is due loan. Out of total debt holders around 43 thousands are maturity crossed debt holders carrying 0.15 percentage as maturity crossed due loan. On an average, total deposit to total loan ratio indicated the lower level utilization of the loan facilities to the client. The microenterprises loan consisted around 25 percentage of total loan. 
Figure 1

Overall Status of Microfinance in Nepal

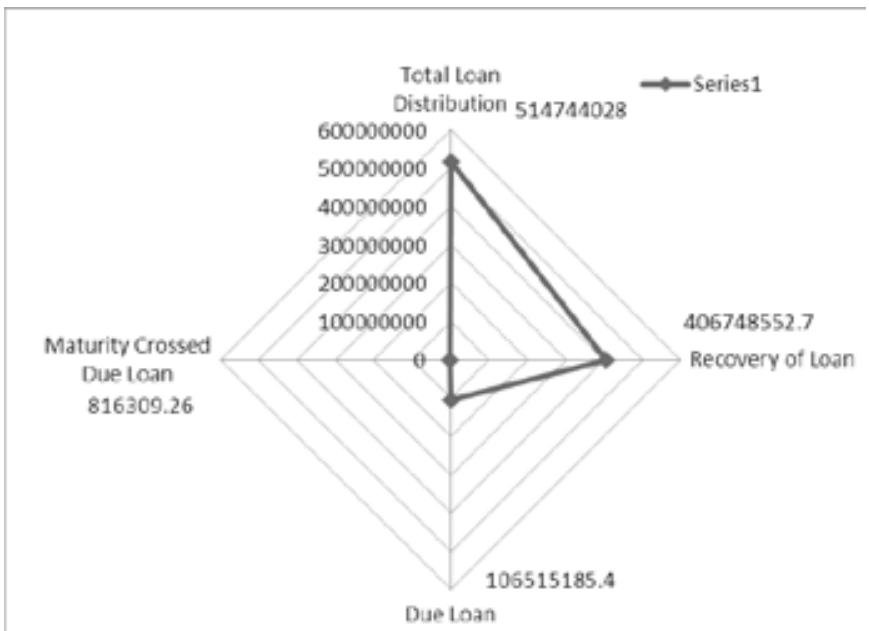

In overall, maturity crossed due loan is below one percentage level indicating low level of indebtedness risk to microfinance institutions in Nepal. Even though, Nepal Grameen Bikas Bank, Nadep, Nepal Sewa, Swedeshi, Mahuli, Mero, NMB, Nerude, Nirdhan Utthan Bank, Deprosc and Swabalamban have high amount of maturity crossed loan in comparison to other microfinance institutions. This implied that these institutions are facing indebtedness challenges in Nepal. The radar diagram in the figure has clearly shown the status of microfinance total loan distribution, recovery of loan, due loan and maturity crossed loan. It has been noticed from the figure that the maturity crossed due loan is in six digit figure, though it becomes negligible in total micro loan figure. The figure has indicated that the movement of recovery of loan is in positive direction.

\section{Conclusions and Implications}

The analytical research on microfinance status, indebtedness and micro credit services of Nepali microfinance institutions have been presented sequentially in the paper. Initially, the concept of finance, microfinance and indebtedness are explained. Later, thematic reviews on the related topic have been done in etymological, ontological, epistemological perspectives followed by microfinance status and indebtedness in Nepal. The series of related literature review have been done to come to the conclusion. All together fifty three microfinance institutions are operating in Nepal. For the study purpose, population has been taken to explore the knowledge on microfinance status in Nepal. The study concluded that microfinance is an emerging institutions operating all over the world basically with the objectives of eliminating the poverty from base line. Nevertheless, the various challenges and problems have been realized while providing microfinance services such as micro credit, micro insurance, training and so on. Indebtedness is one, appearing as a great challenge to microfinance institutions.

The sustainability of microfinance institutions becomes questionable because of this problem. On the other hand, microfinance institutions recovered the loan 


\section{Pravaha Journal-2018}

according to policy, which ultimately affects the living standards of the people. Thus, inverse impact of microfinance institutions may be realized in the mean time. Overindebtedness is one of the major risks for the microfinance industry. First, it contradicts the sectors social mission. It can enhance the poverty of microfinance customers, threaten their social position and lead to psychological disorders and health problems. Secondly, at latest when over indebtedness causes default it represents a threat to sustainability of MFIs.

Among all fifty three institutions, negligible organizations have indebtedness problems. Overall indebtedness challenges have been found in boarder level. The variability in micro credit services rendered by the institutions has shown inconsistency of their focus area, micro product and micro services. The total saving is found attractive however flow of micro credit service is still infant stage. The majority of the clients of microfinance institutions have been found active. It has indicated positive satisfaction of the people. In relation to fiscal year 2072/73 B.S., the members of microfinance institutions are increasing day by day. In general, the microfinance industry should measure customer satisfaction and impact as a standard management tool and place the same importance on these factors as it places on economic indicators. Similarly, regulators and investors should understand the need for customer protection that goes beyond ensuring stable financial institutions.

A mix of regulation and self-regulatory codes of conduct is likely to be most effective. Donors should put as much focus on promoting the measurement of impact, of the client welfare perspective, as they have put on economic self-sustainability and reliable economic performance measurements. Government and regulators could also play an important role in developing systems of debt relief and personal insolvency. In Nepal, government have brought a provision of maintaining seven percentage spread rate for the microfinance customer which may help them to recover their sacrifices but on the other hand, it is the challenge for the MFIs to survive in the market.

\section{References}

American Psychological Association. (2009). Publication Manual of the American Psychological Association. Washington, USA: APA Service Center.

Alex, A K. (2014). Causes and Control of Loan Default/Delinquency in Microfinance Institution in Ghana. American International Journal of Contemporary Research , 36-45.

Armendariz, B., \& Szafarz, A. (2011). On Mission Drift in Microfinance Institutions. The Handbook of Microfinance. World Scientific Publishing, 341-366.

Banerjee, Et.al. (2014). The Miracle of Microfinance? Evidence from a Randomized Evaluation. MIT Department of Economics and NBER.

Bridges, S., \& Disney, R. (2004). Use of Credit and Arrears on Debt among Low-Income Families in the United Kingdom. Fiscal Studies, Vol. 25(1), 1-25.

CGAP, (2003). A Sustainable Approach to Rural Microfinance. CGAP IT INNOVATION SERIES, Micro banking Bulletin.

CGAP, (2003). Donors as Silent Partners in MFI Product Development: Micro Save-Africa and Equity Building Society in Kenya. Case Studies in Donor Good Practices.

Dhakal, N.H. (2007). Towards Expanding the Frontier of Microfinance Services in Nepal.

Re-alignment of the Micro credit in UNDP Supported Projects United Nations Development Programme. Kathmandu: Nepal.

$130 \sim$ | A Journal of Management 
Disney, R., Bridges, S., \& Gathergood, J. (2008). Drivers of Over-Indebtedness: Report to the Department for Business. Enterprise and Regulatory Reform.

Duvendack, M., Palmer-Jones, R., Copestake, J., Hooper, L., Loke, Y., \& Rao, N. (2011). What is the evidence of the impact of microfinance on the well-being of poor people?, EPPI-Centre, Social Science Research Unit, Institute of Education, University of London, London.

Ericksen, J.A., \& Ericksen, E.P. (2014). Overindebtedness in Mexico: It's Effect on Borrowers. Microfinance CEO Working Group, FINCA International.

Godquin, M. (2004). Microfinance Repayment Performance in Bangladesh: How to Improvethe Allocation of Loans by MFIs. World Development, Vol. 32(11), 1909-1926.

Hornby, A. A. (1989). Oxford Advanced Learners Dictionary of Current English, 4th edition Chief editioe A.P. Cowie: Oxford University Press.

Karlan, D., \& Goldberg, N. (2011). Microfinance Evaluation Strategies: Notes onMethodology and Findings. Handbook of Microfinance. USA

Karlan, D., and Zinman, J. (2010). Expanding Credit Access: Using Randomized Supply Decisions to Estimate the Impacts. The Review of Financial Studies, Vol. 23 (1).

Labie, M., \& Mersland, R.( 2010). Corporate Governance Challenges in Microfinance. The Handbook of Microfinance. World Science Publishing. Singapore. Retrieved from doi: 10.1142/9789814295666_0013

Lea, S. E. G., Webley, P., \& Walker, C. M. (1995). Psychological Factors in Consumer Debt: Money Management, Economic Socialization, and Credit Use. Journal of Economic Psychology, Vol.16 (4), 681-701.

Lusardi, A. \& Tufano, P. (2009). Debt Literacy, Financial Experiences, and Overindebtedness, NBER Working Paper Series, No. (14808). Cambridge: MA.

Mersland, R., \& Storm, R. (2010). Microfinance Mission Drift ? World Development, Vol. 38 (1), 28-26.

Nepal Rastra Bank, (2011). Banking and Financial Statistics. Bank and Financial Institution Regulation Department, Statistics Division. Retrieved from Nepal Rastra Bank: http://www.nrb.org.np.

NRB Report, (2013). Some Glimpses of Microfinance Activities in Nepal. Microfinance Promotion and Supervision Department. Kathmandu: Nepal.

NRB Report, (2017). Annual Reports. Microfinance Promotion and Supervision Department. Kathmandu: Nepal.

Schreiner, M. (2004). Scoring Arrears at a Micro lender in Bolivia. Journal of Microfinance, Vol. 6 (2), 65-88.

Schicks, J. (2012). Over-Indebtedness in Microfinance: An Empirical Analysis of Related Factors on the Borrower Level. CERMi, Centre Emile Bernheim - Solvay Brussels School No. (12).

Vogelgesang, U. (2003). Microfinance in Times of Crisis: The Effects of Competition, Rising Indebtedness and Economic Crisis on Repayment Behavior. World Development, Vol. 31(12), 2085-2114.

Viada, L.A., \& Gaul, S. (2012). An Exploration into Whether Investment Contributed to Microfinance Repayment Crises, and Whether Measures of Investment Activity might Serve as Warly Warning Signals for Future Microfinance Crises. Micro Banking Bulletin, Microfinance Information Exchange.

Webley, P., \& Nyhus, E. K. (2001). Life-Cycle and Disproportionate Routes into ProblemDebt. British Journal of Psychology, Vol. 92, 423-446.

WOCCU, (2003). A Technical Guide to Rural- Finance Exploring Products. WOCCU Technical Guide, No. (3). 
Pravaha Journal-2018

Annex

Table 1. Microfinance Microcredit Services and Indebtedness in Nepal

\begin{tabular}{|c|c|c|c|c|c|c|}
\hline Particulars (A) & $\begin{array}{l}\text { Nirdhan } \\
\text { Utthan Bank }\end{array}$ & RMDC & Deprosc & Chhimek & Swabalamban & Sana Kisan \\
\hline Working Districts & 75 & 75 & 75 & 75 & 75 & 75 \\
\hline Total Members & 296388 & 0 & 136049 & 313557 & 218253 & 655 \\
\hline Passive Members & 0 & 0 & 1337 & 3806 & 0 & 0 \\
\hline Total Debt Holders & 206224 & 199 & 91541 & 233657 & 149028 & 550 \\
\hline $\begin{array}{l}\text { Total Loan } \\
\text { Distribution }\end{array}$ & 70066643.17 & 21407264.2 & 26974498.0 & 67797963.2 & 61441709.30 & 48058442.00 \\
\hline Recovery of Loan & 57738214.65 & 15649866.4 & 21443239.0 & 55283761.2 & 53252023.35 & 34063505.51 \\
\hline Due Loan & 12328428.50 & 5757397.76 & 5531259.00 & 12514202.0 & 8189685.95 & 13994934.73 \\
\hline $\begin{array}{l}\text { Maturity Crossed } \\
\text { Due Loan }\end{array}$ & 31912.36 & 0.00 & 39753.00 & 6325.95 & 54856.55 & 12294.62 \\
\hline $\begin{array}{l}\text { Maturity Crossed } \\
\text { Due Loan Holder }\end{array}$ & 1704 & 0 & 1289 & 242 & 2883 & 7 \\
\hline Interest Received & 3657911.04 & 472824.85 & 0.00 & 7328644.69 & 5567936.68 & 4357281.12 \\
\hline Interest Due & 0.00 & 2632.87 & 69299.00 & 1420.05 & 0.00 & 190.59 \\
\hline Loan Loss Provision & 161173.28 & 57573.98 & 83413.00 & 145984.25 & 136066.98 & 219108.90 \\
\hline $\begin{array}{l}\text { Total Deposit/Total } \\
\text { Loan }\end{array}$ & $50.54 \%$ & $0.00 \%$ & $30.26 \%$ & $72.46 \%$ & $51.67 \%$ & $0.00 \%$ \\
\hline $\begin{array}{l}\text { Micro enterprises } \\
\text { loan/Total Loan }\end{array}$ & $10.95 \%$ & $0.00 \%$ & $18.81 \%$ & $18.50 \%$ & $16.31 \%$ & $0.00 \%$ \\
\hline Particulars (B) & Nerude & Naya Nepal & $\begin{array}{l}\text { Mithila } \\
\text { Laghubitta }\end{array}$ & Summit & Swarojgar & $\begin{array}{l}\text { First Microf. } \\
\text { Dev. Bank }\end{array}$ \\
\hline Working Districts & 26 & 10 & 10 & 10 & 10 & 75 \\
\hline Total Members & 109813 & 6021 & 14215 & 33528 & 43335 & 0 \\
\hline Passive Members & 0 & 0 & 0 & 0 & 0 & 0 \\
\hline Total Debt Holders & 73811 & 4905 & 9902 & 22024 & 28042 & 145 \\
\hline $\begin{array}{l}\text { Total Loan } \\
\text { Distribution }\end{array}$ & 20022459.58 & 1142568.00 & 2035934.50 & 5324981.32 & 5057825.57 & 7503000.00 \\
\hline Recovery of Loan & 16927219.47 & 954289.00 & 1599288.73 & 4237070.51 & 3772672.21 & 4063679.30 \\
\hline Due Loan & 3095240.12 & 188279.00 & 443800.72 & 1087910.80 & 1285153.36 & 3439320.70 \\
\hline $\begin{array}{l}\text { Maturity Crossed } \\
\text { Due Loan }\end{array}$ & 31447.01 & 6827.00 & 14192.42 & 3653.07 & 2892.97 & 0.00 \\
\hline $\begin{array}{l}\text { Maturity Crossed } \\
\text { Due Loan Holder }\end{array}$ & 2460 & 0.00 & 499 & 125 & 138 & 0 \\
\hline Interest Received & 504180.64 & 0.00 & 30502.98 & 524137.61 & 0.00 & 314165.34 \\
\hline Interest Due & 25101.32 & 0.00 & 6073.08 & 0.00 & 1226.05 & 0.00 \\
\hline Loan Loss Provision & 40397.77 & 0.00 & 15715.26 & 3658.12 & 15447.21 & 34393.21 \\
\hline $\begin{array}{l}\text { Total Deposit/Total } \\
\text { Loan }\end{array}$ & $36.77 \%$ & $27.78 \%$ & $24.31 \%$ & $41.78 \%$ & $36.93 \%$ & $0.00 \%$ \\
\hline $\begin{array}{l}\text { Micro enterprises } \\
\text { loan/Total Loan }\end{array}$ & $19.05 \%$ & $9.63 \%$ & $19.88 \%$ & $12.85 \%$ & $18.19 \%$ & $0.00 \%$ \\
\hline Particulars (C) & $\begin{array}{l}\text { Nagbeli } \\
\text { Laghubitta }\end{array}$ & Kalika & Mirmire & Jana Utthan & Womi & Laxmi \\
\hline
\end{tabular}


Pravaha Journal-2018

\begin{tabular}{|c|c|c|c|c|c|c|}
\hline Working Districts & 3 & 10 & 15 & 15 & 32 & 75 \\
\hline Total Members & 17027 & 20825 & 25846 & 16569 & 18541 & 55958 \\
\hline Passive Members & 0 & 1973 & 221 & 0 & 900 & 0 \\
\hline Total Debt Holders & 13579 & 12820 & 16044 & 10500 & 11997 & 34720 \\
\hline $\begin{array}{l}\text { Total Loan } \\
\text { Distribution }\end{array}$ & 2904983.84 & 3428970.99 & 2534976.87 & 2000601.13 & 2317559.70 & 7185163.73 \\
\hline Recovery of Loan & 2280957.09 & 2659934.39 & 1709288.98 & 1418861.72 & 1658884.85 & 4969035.80 \\
\hline Due Loan & 624026.75 & 769036.60 & 825687.89 & 581739.41 & 658675.05 & 2216127.92 \\
\hline $\begin{array}{l}\text { Maturity Crossed } \\
\text { Due Loan }\end{array}$ & 12371.40 & 11687.38 & 8243.06 & 5966.77 & 7444.79 & 11015.76 \\
\hline $\begin{array}{l}\text { Maturity Crossed } \\
\text { Due Loan Holder }\end{array}$ & 766 & 313 & 304 & 133 & 182 & 381 \\
\hline Interest Received & 112938.13 & 298150.04 & 201634.53 & 168180.80 & 218198.26 & 343943.73 \\
\hline Interest Due & 7811.86 & 8088.57 & 9907.02 & 985.06 & 5737.42 & 21673.07 \\
\hline Loan Loss Provision & 11425.17 & 15797.06 & 14024.67 & 9701.51 & 15772.64 & 28155.31 \\
\hline $\begin{array}{l}\text { Total Deposit/Total } \\
\text { Loan }\end{array}$ & $27.38 \%$ & $41.82 \%$ & $24.62 \%$ & $24.05 \%$ & $39.10 \%$ & $29.84 \%$ \\
\hline $\begin{array}{l}\text { Micro enterprises } \\
\text { loan/Total Loan }\end{array}$ & $17.07 \%$ & $6.90 \%$ & $11.37 \%$ & $20.22 \%$ & $29.61 \%$ & $8.93 \%$ \\
\hline Particulars (D) & ILFCOM & $\begin{array}{l}\text { Mahila } \\
\text { Sahayatra }\end{array}$ & Kishan & Vijaya & NMB MF & Forward \\
\hline Working Districts & 75 & 75 & 15 & 75 & 75 & 75 \\
\hline Total Members & 11136 & 18314 & 33812 & 21318 & 58081 & 212260 \\
\hline Passive Members & 736 & 1704 & 0 & 2302 & 0 & 0 \\
\hline Total Debt Holders & 6480 & 10167 & 14974 & 14586 & 35720 & 137302 \\
\hline $\begin{array}{l}\text { Total Loan } \\
\text { Distribution }\end{array}$ & 1236075.43 & 1584197.38 & 1645574.16 & 2629397.86 & 4996780.94 & 31893867.7 \\
\hline Recovery of Loan & 836019.54 & 1112260.76 & 1027782.93 & 1735176.59 & 3170015.74 & 25663868.8 \\
\hline Due Loan & 335564.02 & 471936.62 & 617791.23 & 894221.27 & 1826765.24 & 6229998.89 \\
\hline $\begin{array}{l}\text { Maturity Crossed } \\
\text { Due Loan }\end{array}$ & 1967.46 & 13246.85 & 5875.83 & 9880.26 & 32735.80 & 18257.75 \\
\hline $\begin{array}{l}\text { Maturity Crossed } \\
\text { Due Loan Holder }\end{array}$ & 102 & 573 & 86 & 484 & 793 & 955 \\
\hline Interest Received & 106060.07 & 133983.37 & 142371.82 & 217038.28 & 219207.35 & 1083597.33 \\
\hline Interest Due & 5325.14 & 8654.68 & 0.00 & 9251.28 & 17873.05 & 0.00 \\
\hline Loan Loss Provision & 4759.40 & 12768.17 & 3718.75 & 15523.63 & 29628.17 & 77958.82 \\
\hline $\begin{array}{l}\text { Total Deposit/Total } \\
\text { Loan }\end{array}$ & $30.61 \%$ & $15.69 \%$ & $24.43 \%$ & $16.99 \%$ & $22.13 \%$ & $38.29 \%$ \\
\hline $\begin{array}{l}\text { Micro enterprises } \\
\text { loan/Total Loan }\end{array}$ & $1.17 \%$ & $0.20 \%$ & $4.08 \%$ & $19.47 \%$ & $14.48 \%$ & $5.95 \%$ \\
\hline Particulars (E) & Reliable MF & $\begin{array}{l}\text { Mahuli } \\
\text { Community }\end{array}$ & Suryodaya & Mero & Samata & RSDC \\
\hline Working Districts & 15 & 10 & 10 & 75 & 5 & 75 \\
\hline Total Members & 20858 & 59074 & 22682 & 63229 & 12989 & 0 \\
\hline Passive Members & 1481 & 1711 & 0 & 0 & 0 & 0 \\
\hline
\end{tabular}


Pravaha Journal-2018

\begin{tabular}{|c|c|c|c|c|c|c|}
\hline Total Debt Holders & 10209 & 50619 & 13196 & 43917 & 8685 & 152 \\
\hline $\begin{array}{l}\text { Total Loan } \\
\text { Distribution }\end{array}$ & 1976868.63 & 6909591.09 & 2304696.40 & 8279024.59 & 1170535.62 & 3435139.00 \\
\hline Recovery of Loan & 1453106.62 & 5666702.07 & 1663645.17 & 5253817.10 & 791251.99 & 1801683.66 \\
\hline Due Loan & 457045.30 & 1242889.02 & 641051.22 & 2403296.53 & 379283.64 & 899156.00 \\
\hline $\begin{array}{l}\text { Maturity Crossed } \\
\text { Due Loan }\end{array}$ & 14440.91 & 22194.39 & 4408.64 & 23588.45 & 2841.55 & 0.00 \\
\hline $\begin{array}{l}\text { Maturity Crossed } \\
\text { Due Loan Holder }\end{array}$ & 378 & 1550 & 147 & 1926 & 217 & 0 \\
\hline Interest Received & 160791.38 & 652159.55 & 198158.00 & 0.00 & 65763.89 & 181479.40 \\
\hline Interest Due & 4949.25 & 18332.57 & 6791.63 & 0.00 & 3615.13 & 8147.00 \\
\hline Loan Loss Provision & 11032.12 & 32597.00 & 8461.01 & 23588.45 & 6298.59 & 9016.00 \\
\hline $\begin{array}{l}\text { Total Deposit/Total } \\
\text { Loan }\end{array}$ & $35.75 \%$ & $47.87 \%$ & $39.19 \%$ & $20.79 \%$ & $35.78 \%$ & $0.00 \%$ \\
\hline $\begin{array}{l}\text { Micro enterprises } \\
\text { loan/Total Loan }\end{array}$ & $12.92 \%$ & $2.38 \%$ & $2.09 \%$ & $11.18 \%$ & $23.02 \%$ & $0.00 \%$ \\
\hline Particulars (F) & Samudayik & National & $\begin{array}{l}\text { Nepal } \\
\text { Grameen } \\
\text { Bikas Bank }\end{array}$ & $\begin{array}{l}\text { Nepal Sewa } \\
\text { MF }\end{array}$ & Unnati MF & Swedeshi MF \\
\hline Working Districts & 10 & 75 & 75 & 3 & 10 & 75 \\
\hline Total Members & 33502 & 44650 & 210250 & 4601 & 16702 & 44738 \\
\hline Passive Members & 0 & 0 & 19801 & 0 & 0 & 0 \\
\hline Total Debt Holders & 11868 & 33776 & 134569 & 2364 & 10241 & 29440 \\
\hline $\begin{array}{l}\text { Total Loan } \\
\text { Distribution }\end{array}$ & 3113023.28 & 4973586.35 & 66357353.51 & 376991.50 & 1224449 & 3900234.25 \\
\hline Recovery of Loan & 2569654.13 & 3327188.76 & 58635566.13 & 196590.50 & 640727 & 2506864.46 \\
\hline Due Loan & 543370.54 & 1646397.59 & 7721787.38 & 180401.00 & 583696 & 1393369.79 \\
\hline $\begin{array}{l}\text { Maturity Crossed } \\
\text { Due Loan }\end{array}$ & 6369.57 & 7798.96 & 290278.00 & 28378.69 & 0 & 37028.87 \\
\hline $\begin{array}{l}\text { Maturity Crossed } \\
\text { Due Loan Holder }\end{array}$ & 230 & 225 & 19801 & 467 & 0 & 1250 \\
\hline Interest Received & 0.00 & 322626.97 & 2557073.00 & 25274.20 & 0 & 267912.70 \\
\hline Interest Due & 0.00 & 14821.26 & 479988.00 & 422.71 & 4891 & 14445.02 \\
\hline Loan Loss Provision & 15822.07 & 21746.42 & 327413.00 & 2509.88 & 5837 & 23519.63 \\
\hline $\begin{array}{l}\text { Total Deposit/Total } \\
\text { Loan }\end{array}$ & $37.04 \%$ & $19.80 \%$ & $29.23 \%$ & $13.71 \%$ & $26.28 \%$ & $24.48 \%$ \\
\hline $\begin{array}{l}\text { Micro enterprises } \\
\text { loan/Total Loan }\end{array}$ & $0.23 \%$ & $0.00 \%$ & $10.36 \%$ & $15.73 \%$ & $12.12 \%$ & $12.07 \%$ \\
\hline Particulars (G) & Nadep & Support MF & $\begin{array}{l}\text { Aarambha } \\
\text { MF }\end{array}$ & Janasewi & Choutari & Ghodi Ghoda \\
\hline Working Districts & 75 & 10 & 15 & 10 & 10 & 10 \\
\hline Total Members & 48985 & 5399 & 9165 & 6736 & 14171 & 801 \\
\hline Passive Members & 0 & 0 & 17 & 159 & 53 & 0 \\
\hline Total Debt Holders & 38479 & 4493 & 5977 & 4412 & 8284 & 467 \\
\hline $\begin{array}{l}\text { Total Loan } \\
\text { Distribution }\end{array}$ & 5661340.58 & 514898.00 & 566509.50 & 412820.50 & 735598.99 & 42822.00 \\
\hline
\end{tabular}


Pravaha Journal-2018

\begin{tabular}{|c|c|c|c|c|c|c|}
\hline Recovery of Loan & 3589364.58 & 249199.05 & 275893.88 & 195942.14 & 350216.91 & 16333.00 \\
\hline Due Loan & 2071976.00 & 265698.95 & 290615.62 & 216878.36 & 385382.08 & 26489.00 \\
\hline $\begin{array}{l}\text { Maturity Crossed } \\
\text { Due Loan }\end{array}$ & 31247.07 & 2174.14 & 300.85 & 321.68 & 1867.73 & 0.00 \\
\hline $\begin{array}{l}\text { Maturity Crossed } \\
\text { Due Loan Holder }\end{array}$ & 2375 & 227 & 19 & 14 & 38 & 0 \\
\hline Interest Received & 548774.05 & 36550.14 & 32811.91 & 20759.16 & 45587.22 & 3700.00 \\
\hline Interest Due & 0.00 & 2567.77 & 2503.70 & 207.57 & 53.28 & 0.00 \\
\hline Loan Loss Provision & 49866.02 & 2987.79 & 3059.53 & 2423.15 & 3947.93 & 265.00 \\
\hline $\begin{array}{l}\text { Total Deposit/Total } \\
\text { Loan }\end{array}$ & $30.52 \%$ & $11.19 \%$ & $13.70 \%$ & $18.88 \%$ & $23.06 \%$ & $7.78 \%$ \\
\hline $\begin{array}{l}\text { Micro enterprises } \\
\text { loan/Total Loan }\end{array}$ & $1.20 \%$ & $0.00 \%$ & $7.37 \%$ & $1.42 \%$ & $2.72 \%$ & $11.65 \%$ \\
\hline Particulars (H) & Asha & Nepal Agro & $\begin{array}{l}\text { Rama } \\
\text { Roshan }\end{array}$ & Creative & Gurash & Ganapati MF \\
\hline Working Districts & 75 & 10 & 10 & 3 & 10 & 10 \\
\hline Total Members & 11314 & 8645 & 1597 & 1839 & 3034 & 3946 \\
\hline Passive Members & 25 & 0 & 30 & 4 & 3 & 0 \\
\hline Total Debt Holders & 6855 & 5585 & 884 & 933 & 2258 & 2725 \\
\hline $\begin{array}{l}\text { Total Loan } \\
\text { Distribution }\end{array}$ & 475546.00 & 291028.00 & 62096.55 & 55567.00 & 204254.00 & 190087.50 \\
\hline Recovery of Loan & 84171.33 & 84460.52 & 21772.96 & 13371.45 & 57501.02 & 33543.44 \\
\hline Due Loan & 391374.67 & 206567.48 & 40323.60 & 42195.55 & 146752.98 & 156544.06 \\
\hline $\begin{array}{l}\text { Maturity Crossed } \\
\text { Due Loan }\end{array}$ & 0.00 & 0.00 & 0.00 & 0.00 & 216.70 & 0.00 \\
\hline $\begin{array}{l}\text { Maturity Crossed } \\
\text { Due Loan Holder }\end{array}$ & 0 & 0 & 0 & 0 & 21 & 0 \\
\hline Interest Received & 13174.76 & 16471.85 & 5746.65 & 2792.81 & 7621.33 & 5971.14 \\
\hline Interest Due & 3143.06 & 86.16 & 0.00 & 0.00 & 32.99 & 1364.74 \\
\hline Loan Loss Provision & 0.00 & 2065.67 & 114.14 & 421.86 & 1467.53 & 1566.42 \\
\hline $\begin{array}{l}\text { Total Deposit/Total } \\
\text { Loan }\end{array}$ & $9.44 \%$ & $18.17 \%$ & $14.22 \%$ & $13.07 \%$ & $5.12 \%$ & $11.00 \%$ \\
\hline $\begin{array}{l}\text { Micro enterprises } \\
\text { loan/Total Loan }\end{array}$ & $11.60 \%$ & $0.00 \%$ & $11.37 \%$ & $1.20 \%$ & $0.00 \%$ & $0.62 \%$ \\
\hline Particulars (I) & Infinity MF & $\begin{array}{l}\text { Adhikhola } \\
\text { Laghubitta }\end{array}$ & $\begin{array}{l}\text { Swabhiman } \\
\text { MF }\end{array}$ & Sparsh & Sabaiko & Total \\
\hline Working Districts & 75 & 10 & 10 & - & 75 & - \\
\hline Total Members & 3494 & 3119 & 1592 & - & 5 & $2,338,618$ \\
\hline Passive Members & 5 & 0 & 0 & - & 0 & 36,268 \\
\hline Total Debt Holders & 2439 & 1364 & 630 & - & 1 & $1,573,739$ \\
\hline $\begin{array}{l}\text { Total Loan } \\
\text { Distribution }\end{array}$ & 184435.00 & 80156.00 & 53917.00 & - & 20.00 & $514,744,028 . .0$ \\
\hline Recovery of Loan & 32119.49 & 9183.10 & 1765.70 & - & 0.00 & $406,748,552.7$ \\
\hline Due Loan & 152315.51 & 70972.90 & 52151.30 & - & 20.00 & $106,515,185.4$ \\
\hline
\end{tabular}


Pravaha Journal-2018

\begin{tabular}{|c|c|c|c|c|c|c|}
\hline $\begin{array}{l}\text { Maturity Crossed } \\
\text { Due Loan }\end{array}$ & 5.00 & 0.00 & 0.00 & - & 0.00 & $816,309.26$ \\
\hline $\begin{array}{l}\text { Maturity Crossed } \\
\text { Due Loan Holder }\end{array}$ & 1 & 0 & 0 & - & 0 & $43,305.00$ \\
\hline Interest Received & 5141.01 & 1240.30 & 145.27 & - & 0.00 & $31,180,615.35$ \\
\hline Interest Due & 11731.19 & 0.00 & 382.07 & - & 0.00 & $779,725.99$ \\
\hline Loan Loss Provision & 1523.16 & 709.73 & 521.51 & - & 0.00 & $1,710,945.82$ \\
\hline $\begin{array}{l}\text { Total Deposit/Total } \\
\text { Loan }\end{array}$ & $18.04 \%$ & $18.39 \%$ & $9.01 \%$ & - & $98.90 \%$ & $1357.86 \%$ \\
\hline $\begin{array}{l}\text { Micro enterprises } \\
\text { loan/Total Loan }\end{array}$ & $0.00 \%$ & $4.41 \%$ & $0 \%$ & - & $0.00 \%$ & 4.39 \\
\hline
\end{tabular}

Source: Nepal Rastra Bank 